\section{TREEVIA QUIZ}

1. Canadian forests contain how many different native species of trees? a) 29, b) 107 , c) 131 .

2. British Columbia has 7 of Canada's 12 forest regions - more than any other province. Do you know why?

3 . The grasslands of the southern prairie provinces support several species of poplars. In what type of habitat or growing conditions are these tress most found? 4. Which solvent, used as a paint thinner, comes from trees?

5. Which of the following is made from wood pulp? a) cellophane, b) polyester, c) Gore-Tex

6. How is the scent in pine air fresheners obtained?

7. Since plants make their own food, what name do ecologists give to them? a) primary producers, b) primary consumers, c) decomposers.

8. Plants are the only living things that can produce their own food. True or false?

9. Chlorophyll is not the only pigment in a green plant. What other pigments are responsible for the orange, yellow and red colours in leaves?

'sә八вว UI SInojo

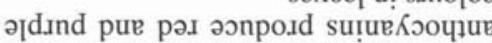

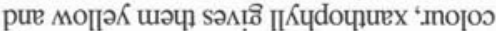

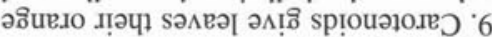
pooj uмо пाәч)

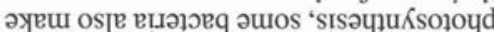

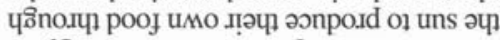

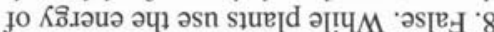
s.ıüns

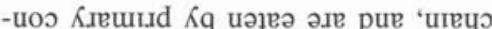

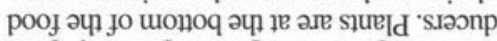

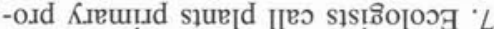

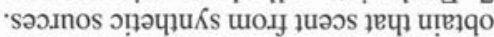

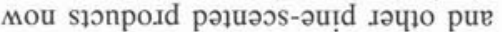

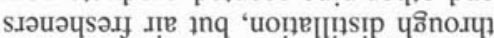

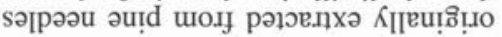

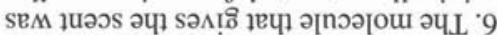
-dind poom uory

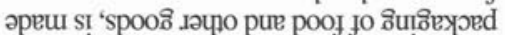

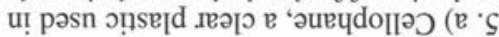

'ep

-eurอ ınoy әреu SI 'uononpo.Id d[nd poom fo ssəoo.Id

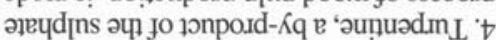
'suŝno[s Io suotssaldəp tәм punore uadse

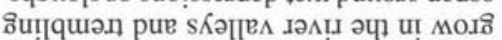

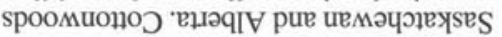
'

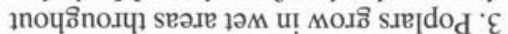
spreurue pur

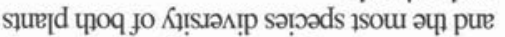

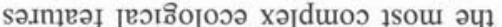
sey os[e II 'әэuा

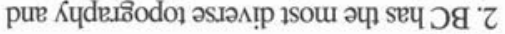
səon

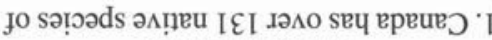
SYGMSNV force trees to adopt a defense-reactive posture and arm them against environmental stress. They stabilize membranes, protect photosynthesis and reduce seedling mortality. Compounds found to be effective include conifer extracts, polyamines, brassinolides, and Ambiol (a new synthetic antioxidant). One patent was granted and several papers have been published showing that these compounds harden plants, reduce the amount of water and nutrients needed and promote growth. Only a single treatment was required and seedlings grew faster and were less prone to damping off and other diseases. Another method of treating plants involved use of short wavelength radiation. All treatments increased the tolerance of seedlings to heat, frost and drought and faster growth was observed when seedlings recovered from stress. Since diameter and root growth increased more than height, seedlings were sturdier and developed a much larger root system. The novelty in this work lies in the ability to utilize natural plant compounds. Simple, cost-effective methods were developed that were environmentally sound. For a few cents per seedling it was possible to produce hardier, faster-growing seedlings that required less fertilizer, herbicide and irrigation.

\section{Recent publications}

Darlington, A., K. Vishnevetskaia and T.J. Blake. 1996. Growth enhancement and antitranspirant activity following seed treatment with a derivative of 5-hydroxybenzimiazole (Ambiol) in four drought stressed agricultural species. Physiologia Plantarum 97: $217-222$.

Lada R. Rajasekaran and Blake, T. J. 1998. Early growth invigoration of jack pine seedlings by natural plant growth regulators. Trees: 12: 420-423.

Lada R. Rajasekaran and Blake, T.J. 1999. New plant growth regulators protect photosynthesis and enhance growth under stress. Journal of Plant Growth Regulation (in press).

Amalia Veneziano

\section{NEW BRUNSWICK Research}

Robert A. Douglas is just back from two weeks at the University of Ulster, Jordanstown, Northern Ireland, where he used a full-scale lab apparatus they have to measure tire/road interface stresses. This is going to be a significant input to a study on "central tire inflation" (CTI) he has underway. CTI systems permit the drivers of heavy log trucks to deliberately deflate their tires when poor road conditions are encountered, and re-inflate them when better roads are traveled on.

\section{Presentations/Workshops}

Dave MacLean, Dean of the Faculty of Forestry \& Environmental Management, gave an invited presentation entitled Implementation of a sustainable management planning process in the Fundy Model Forest at the Canadian Model Forest Network Meeting, Sept. 8-9, 1999 in Halifax.

Liz Whamond, executive assistant to the Dean, is attending the VII Cochrane Colloquium on Evidence-Based Medicine in Rome, October 5 to 9th, 1999. She is one of about 43 consumers from around the world participating.

Prof. Rob Douglas, Dave Daugharty and one of Prof. Douglas' grad students Randy Rickard, took part in a workshop on "Maintaining Water Quality in Woodlands Operations" held in Moncton, NB on August 11 and 12, 1999. Prof. Douglas presented his paper entitled, Planning when constructing forest roads and stream crossings.

\section{Appointments}

Dr. Marek Krasowski has accepted the Tree Biologist position, effective 1 December 1999. Marek has a Forest Engineering Technologist degree from the Academy of Agricultural Sciences in Poznan, Poland, plus MSc and $\mathrm{PhD}$ degrees from the Department of Biology, University of Victoria. His $\mathrm{PhD}$ dissertation was entitled The development of

\title{
WANTED
}

CIF urgently needs copies of the January-February 1997 issue of the Forestry Chronicle. If you have unwanted copies please send them to the CIF National Office. 
roots and root systems in white spruce, Picea glauca ([Moench] Voss), and the influence of cultural treatments on root morphology, anatomy, and the capacity to conduct water. Since 1990 he has beene mployed as a research scientist for the BC Ministry of Forests, and since 1998 , also as manager of the Red Rock Research Station in Prince George, BC. $\mathrm{He}$ has published on various aspects of crown and root development and anatomy of seedlings and trees.

Research interest include the relationship between plant structure and function, the mechanisms of growth and dormancy regulation, ecophysiology and stress physiology of forest tree species.

\section{Published Materials}

Robert A. Doulgas's book, entitled Delivery, the Transportation of Raw Natural Resource Products from Roadside to Mill is just headed off to the printers. He wrote it to support one of the faculties technical electives, and it is also available for general sale.

Tony Diamond is currently finalizing the editing of a volume to be published shortly by the Society of Canadian Ornithologists. Entitled: Biology and Conservation of Forest Birds, Society of Canadian Ornithologists Special Publication No. 1, August 1999.

\section{Students and Faculty to Visit Chile}

Each year, the Faculty of Forestry and Environmental Management at the University of New Brunswick offers a directed regional studies course, focusing on the social, cultural, historical and biological factors influencing forest management practices employed in a certain region of the world. Previous successful ventures include the Czech Republic, Germany, South Eastern and Central US.

The purpose of the course is to introduce students and faculty to some of the forest management principles applied in various parts of the world. The course involves a trip to the chosen site, where the group can experience the development and implementation of forest operations within the region. At the same time, the knowledge of forest issues and management principles in Canada is brought abroad. This year, the course will take place in Chile. A two-week trip is planned, and there exists an opportunity for professional foresters from Canada to accompany the group. Any interested readers should contact Dr. John kershaw (Kershaw@unb.ca) for further information. A complete program description can be found at www.unb.ca/web/ standint/asdm/regioncourse.html.

Chile has long been dependent on the forest as a viable resource. The native Chileans have been clearing and burning land for agriculture and grazing since before the coming of the Spanish. There is great movement in Chile to employ sustainable practices, to ensure they maximize the benefits of their productive forestlands. Canadians are heavily involved in forest management strategies in Chile. The study of the area will focus on four topics of interest: 1. A study of the intensive planting strategies employed in Chile.

2. An investigation of village/community land use, and its relationship to forest practices.

3. Native forest management.

4. Logging operations in mountainous terrain.

The group is looking for sponsors to help pay for this trip, and is hoping that Canadian companies will lend their support. The estimated cost of travel is approximately $\$ 2000$ (CAN) per student, a large dent in his/her budget!! The support of the Canadian forest industry will be sought over the next two months via telephone and e-mail.

This is an excellent opportunity for Canadian forestry students and professionals to learn about forestry practices abroad and take Canadian knowledge of forest management to other reaches of the earth. At the University, all will benefit from expanding their knowledge in forestry to an international level. Many issues faced in Chile parallel those in Canada, such as Native issues, community involvement in forest management strategies, and steep terrain operations. Knowledge gained in Chile can thus be applied to professional careers in Canada. It is a positive program for all those involved.

Dirk R. Nielson

NNOELEe
It has come to our attention that
some copies of the September/
October 1999 issue of The Forestry
Chronicle have missing and/or
duplicate pages. Please check
your copy and let us know.

\section{ARBORICOLLE}

1. Combien d'essences d'arbres indigènes trouve-t-on dans leas forêts canadiennes? a) 29, b) 107 , c) 131.

2. La Colombie-Britanniue abrite 7 des 12 régions forestères du Canada - plus que toute autre province. Savez-vous pourquoi? 3. Plusiers essences de peupliers poussent dans les pâturages du sud des Prairies. Dans quel genre d'habitat trouve-t-on généralement ces arbres, ou quelles conditions favorisent leur croissance?

4. Quel solvent, utilisée comme diluant, vient de l'arbre?

5. Lequel des produits suivants provient de la pâte de bois? a) le cellophane, b) le polyester, c) le Gore-Tex.

6. Comment obtient-on l'arôme des rafraîchisseurs d'air à odeur de pin?

7. Comme les plantes fabriquent leur propre nourriture, quel nom leur donnent les écologistes? a) producteurs primaires, b) consommateurs primaires, c) agents de décomposition

8. Les plantes sont les seuls êtres vivantes à pouvoir produire leur propre nourritur. Vrai ou faux?

9. La chlorophylle n'est pas le seul pigment d'une plante verte. Quels autres pigments qui donnent aux feuilles leur coloration orange, jaune et rouge?

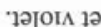
วฮึกo. suoṇe.

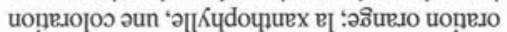

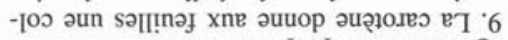
a.mun

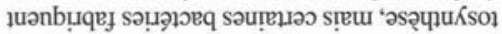

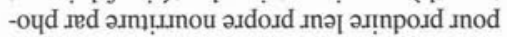

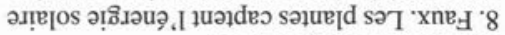
'sarneuut sinəı⿻uuuosuos

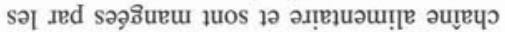

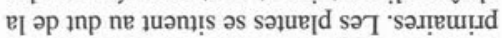

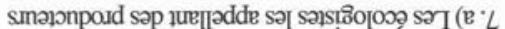

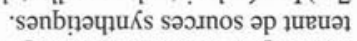

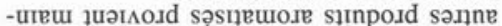

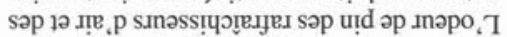

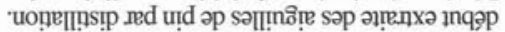

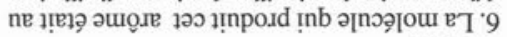
'sioq әp

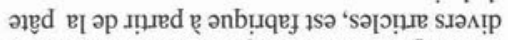

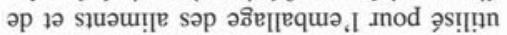

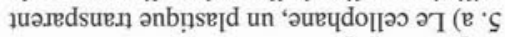
'sıarded ja sajed ap

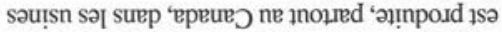

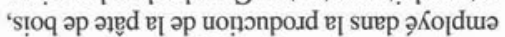

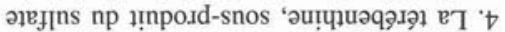

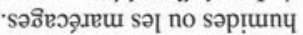

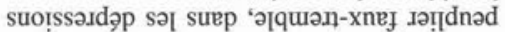
ә 12 'sә[ย!̣

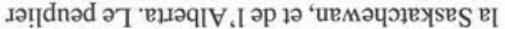

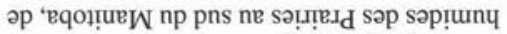
səuoz səI surp juəssnod sıəIIdnad sə7 $\cdot \varepsilon$ 'sә[euturu ja sә[в]

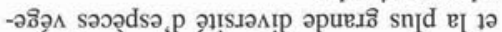

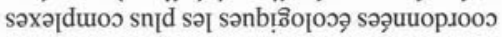

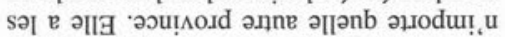

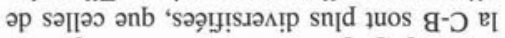

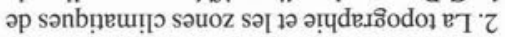
'səuอุô!pu! saxqre,p

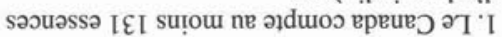
SASNOdG্র 